\title{
How Indonesian Companies Facing The Global Economic Disruption and It Impacts
}

Over time, the economy and business are experiencing rapid development every year. this causes business competition to also be tighter. Companies are also required to be able to innovate more in line with changing situations in their environment, especially following technological changes. Those who do not survive or have no innovation may fail. Competition between companies is expanding and becoming a global competition. (Tayibnapis et al., 2019)

The global economic disruption or economic crisis that had hit and disrupted the global economy, for example, had occurred in December 2018. In the midst of a crisis that impacted on the world economy, a McKinsey report entitled "Leading Through Uncertainty" explained several guidelines for companies to deal with uncertainty and overcome economy Crysis. where companies must be able to evaluate a series of unusual macroeconomic and strategic responses and strive to make their companies more flexible, resilient and aware.

The unbalanced global economic conditions in 2018 and global financial uncertainty also affected companies in Indonesia. which causes the level of ease of doing business in Indonesia, which was initially ranked 72 out of 190 countries in 2017, has decreased to 73 in 2018. even though the decline did not really impact investment, both domestically and internationally. (Tayibnapis et al., 2019).

In the midst of an uncertain global economic system, the role of a practice called Good Corporate Governance (GCG) has emerged. Where GCG is a set of rules that manage, regulate and also oversee the relationship between organizational managers and stakeholders in the organization in an effort to increase company value and market valuation. (Tayibnapis et al., 2019).

GCG is believed to be the best practice in the market economy system, and is beneficial to encourage healthy competition and a conducive business climate. With the implementation of GCG, an organizational culture, disclosure of information, proper risk control and an effective audit system can be created. GCG practices for organizations are directed at supporting economic stability and growth.

Specifically, GCG is based on three main pillars, (1) The state as a policy maker and a maker of laws and regulations. and law enforcement to support a healthy, efficient and transparent business climate, (2) The business world as a market participant implementing GCG as a basic 
guideline for running their business, and (3) The community as users of products / services and parties affected by the existence of the company play a role in exercising objective social control.

During the global economic crisis that also hit Indonesia in 2018, the financial services authority (OJK) considered that the GCG assessment was a reflection of a country. He considered that one of the reasons Indonesia was also affected by the financial crisis was that many companies in Indonesia had not evenly applied the principles of GCG itself. Quoted from Liputan6, The Chairman of the OJK Board of Commissioners, Muliaman D Hadad said, in recent years the failure of GCG implementation has been the cause of deteriorating economic conditions in Indonesia. He said that the failure to implement GCG in companies in Indonesia had triggered the financial crisis in the last 10 years.

To deal with economic disruptions and the 4.0 industrial revolution, the competitiveness of companies in Indonesia is very much dependent on the ability of these companies to take advantage of changes from rapidly growing technological advances in order to survive, develop, and also provide significant added value. (Tayibnapis et al., 2019)

Economic disruption has had an impact on many economic aspects as well as on companies and workers in Indonesia. Likewise when entering the industrial revolution 4.0. However, it can be said that Indonesia itself is sufficient to face this new era. The implementation of the industrial revolution 4.0 is likely to double the level of labor productivity above the cost of labor, can also restore net industrial exports, and allocating increased GDP to $\mathrm{R} \& \mathrm{D}$ and technological innovation.

In order to reach this, the Government of Indonesia has formed main strategies as follow: formation of innovation ecosystem, improvement of human resources quality, harmonization of policy and regulations, empowerment of UMKM, reforming the flow of materials, building the national digital infrastructure, attracting foreign direct investment, industrial zone redesign, and accommodating sustainability standard.

Quoted from the BKPM website in the Indonesia Economic Updates section, it is said that the Ministry of Industry is promoting 'Making Indonesia 4.0', which is an integrated roadmap for implementing various strategies in entering the era of the industrial revolution 4.0. This roadmap requires collaborative action from many stakeholders ranging from government agencies, associations and industry players, as well as academic elements.

According to Airlangga Hartanto as Minister of Industry, Indonesia has entered a new era of Industry 4.0 which is marked by increased interaction, connectivity, more convergence of 
people, machines and other resources which are the result of the willingness of information and communication technology.

Companies that have implemented GCG are proven to be able to carry out all strategies and management systems properly and bring trust to stakeholders. In general, from the aspects of output, outcome, and impact, companies that implement GCG show significant progress where they are able to encourage aspects of accountability, trust and transparency. GCG also helps to empower functions in business units and increase the independence of the company.

\section{(Tayibnapis et al., 2019)}

One of the state-owned enterprises in Indonesia that implements GCG is PLN. The Company realizes that the current implementation of GCG is not only a fulfillment of obligations, but also a necessity in carrying out the Company's business activities in order to maintain sustainable business growth, increase corporate value and as an effort for the Company to survive in competition. The implementation of GCG at PLN is also in accordance with the provisions and does not violate the principles of GCG, where these principles are also manifested by, among others, the establishment of a GCG management function under the Corporate Secretary who specifically handles and monitors the effectiveness of GCG implementation in the Company.

\section{REFERENCES}

Tayibnapis, A. Z., E. Wuryaningsih, L., \& Gora, R. (2019). Companies in Indonesia in the vortex of global economic disruption. 308(Insyma), 174-177. https://doi.org/10.2991/insyma-19.2019.45

BKPM. (2017). Indonesia Economic Update Making Indonesia 4 . 0 : Indonesia 's Strategy to Enter the 4th Generation of Industry Revolution. 2576(44), 62807. https://www.investindonesia.go.id/en/why-invest/indonesia-economic-update/makingindonesia-4.0-indonesias-strategy-to-enter-the-4th-generation-of-ind

Liputan6. (n.d.). Tata Kelola Perusahaan Buruk Jadi Pemicu Krisis Ekonomi Dunia. 19. https://www.liputan6.com/bisnis/read/817550/tata-kelola-perusahaan-buruk-jadipemicu-krisis-ekonomi-dunia 